\title{
Properties of bleached pulp sheets of avocado wood (Persea americana Mill.) pulped by Kraft and Soda processes
}

\author{
Vargas R. , J.R. Sanjuán D. ${ }^{1}$ \\ J.A. Silva G. , J. Rivera P. \\ F.J. Fuentes T. ${ }^{1}$, H.G. Richter ${ }^{2}$
}

RESUMEN

\begin{abstract}
Astillas de madera de aguacate (Persea americana Mill.) fueron cocidas por medio de los procesos convencionales Sosa y Kraft. Las pulpas celulósicas obtenidas fueron blanqueadas con una secuencia libre de cloro elemental $O-D_{1}-E_{o p}-D_{2}$, estableciendo previamente las condiciones de reacción para la primera etapa de dióxido de cloro $\left(D_{1}\right)$. Los resultados obtenidos muestran que la madera de aguacate es pulpeada con mayor facilidad que una madera dura como el eucalipto. De igual forma muestra mayor facilidad de blanqueo, alcanzando niveles de blancura de $92 \%$ ISO comparados con $84 \%$ ISO que se logra con el eucalipto con la misma secuencia de blanqueo. La pulpa de madera de aguacate obtenida con el proceso Kraft demandó más reactivos durante el blanqueo que la pulpa de madera de aguacate obtenida con el proceso a la sosa. Por otra parte, las propiedades de resistencia físico-mecánica, no fueron afectadas negativamente por los procesos de blanqueo, mostrando mayor resistencia la pulpa Kraft. Finalmente, se aprecia similar resistencia de las pulpas de madera de aguacate y las de eucalipto, por lo que se considera que esta materia prima podría ser una opción de suministro de fibras celulósicas.
\end{abstract}

PALABRAS CLAVE:

Blanqueo libre de cloro elemental, dióxido de cloro, Persea americana Mill, propiedades físico-mecánicas, pulpeo kraft, pulpeo a la sosa.

\section{ABSTRACT}

Chips of avocado wood (Persea americana Mill.) were pulped by means of conventional Soda and Kraft pulping processes. The pulps were bleached with an elemental-chlorine-free sequence $\mathrm{O}-$ $D_{1}-E_{o p}-D_{2}$, pre-setting reaction conditions for the first chlorine dioxide stage $\left(D_{1}\right)$. The results show that during the chemical pulping process, avocado wood is easier to cook than other hardwoods such as eucalyptus. The avocado pulp also showed a very good bleachability, reaching brightness levels of up to $92 \%$ Iso compared to $84 \%$ for eucalyptus after the ECF bleaching sequence. The avocado Kraft pulps required more chemical input in the bleaching sequence than the Soda pulps. On the other hand, the physico-mechanical properties of the pulp were not notably reduced by the bleaching process, the Kraft pulp being stronger than the soda pulp. Strength properties of avocado are similar to those of eucalyptus; therefore this raw material constitutes a worthwhile choice for cellulosic fiber supply.

KEY WORDS:

Elemental chlorine free bleaching, chlorine dioxide, Persea americana Mill, physical-mechanical properties, Kraft pulping, soda pulping. 


\section{INTRODUCTION}

The Avocado tree (Persea americana Mill.) is probably native to México and Central America (Record \& Hess, 1944; Kopp, 1966). It is cultivated for fruit production in many countries around the world. Orchard trees grow to an average height of $10-15 \mathrm{~m}$ and a diameter of around $60 \mathrm{~cm}$, and tend to form numerous low branches, however with shape and dimensions which do not lend themselves for quick and easy conversion into sawn timber. According to FAO reports (FAOSTAT, 2004 ), around 416.000 ha are cultivated with avocado trees worldwide. The total world production of avocado fruit is estimated at 3.188.000 tons. Large avocado plantations were established in Mexico in the 1960's and 1970's mainly in the states of Michoacán and Puebla. In fact, México is the world's largest producer with about 102500 ha under cultivation, planted with ca. 100 trees per ha, and a total annual production of 1.040 .000 tons of fruit. This represents nearly one third of world production (FAOSTAT, 2004).

It is evident that the main concern of the avocado growers is fruit production, which is strongly affected by the absence of light and air due to the dense canopies of the plantations. To increase or maintain current avocado production, the plantations require frequent pruning and thinning operations generating large amounts of biomass, as about $10 \%$ of the planted land must be cleared annually in order to avoid infection of healthy trees by those infested with plagues. In México about 2 million trees are thus removed yearly from the plantations generating approximately 500.000 cubic meters of round wood. Most of this raw material is simply burned without deriving any economic benefit. Only a small proportion is converted into sawn timber for packaging crates, parts of musical instruments, etc. (López, 1999).
As a consequence, a specific avocado wood research program was proposed with the general objectives of determining the properties of the residual wood, search for potential uses and, in particular, examine the suitability of this raw material for pulp and paper production. Papermaking with avocado wood is of particular interest because

- the pulp and paper industry in México has a very limited supply of raw materials, and

- Avocado wood fibers possess adequate morphological characteristics for papermaking (Silva et al., 1999).

\section{OBJECTIVE}

The objective of this study was to produce a bleached pulp of $88-90 \%$ ISO brightness (Elrepho), with chips of avocado wood (Persea americana Mill.) pulped by means of kraft and soda processes, meeting the environmental considerations for the mills of the future.

\section{MATERIALS AND METHODS}

Debarked logs of avocado wood from regular plantation maintenance were chipped with a pilot scale Bruks Mekaniska AB type 980AA chipper with 2 radial blades and then classified by length and thickness. The chips that passed through the $8 \mathrm{~mm}$ mesh sieve but were retained on the $7 \mathrm{~mm}$ mesh sieve were selected for pulping, according to the method D35X (Hatton, 1979).

The screened chips were cooked in one liter stainless steel digesters using Kraft and Soda pulping processes with the objective to produce pulps with a Kappa number of approximately 18 units in both pulping processes. The conditions of the pulping stage were as follows: $13-14 \%$ of 
active alkali (AA) as $\mathrm{Na}_{2} \mathrm{O}$, maintaining a constant liquor to wood ratio of $5: 1$ and a cooking time of 90 minutes at $170^{\circ} \mathrm{C}$. The produced pulps were separated from the residual liquor, washed, and passed through a $0.15 \mathrm{~mm}$ slotted flat screen.

The following parameters were evaluated for the pulps passed through the screen: residual lignin by Kappa number (TAPPI T-236), viscosity (TAPPI T-230), percent of rejects and yield. Residual active alkali in the liquor was evaluated by means of a potentiometric titration.

The following elemental chlorine free (ECF) bleaching sequence was applied to the screened pulps: oxygen reinforced with soda $(\mathrm{O})$, first chlorine dioxide (D1), oxygen-peroxide extraction $\left(\mathrm{E}_{\mathrm{OP}}\right.$ ) (Senior, 1998), and finally a second chlorine dioxide (D2) with the reaction conditions shown in table 1 . The strength properties of bleached and unbleached pulps were evaluated using TAPPI standard methods.

\section{RESULTS AND DISCUSSION}

\section{Pulping}

The principal parameters of the pulps obtained from both processes are listed in table 2, those with a nearly equal Kappa number (approximately 18), indicated by an asterisk, were chosen for this essay.

Table 1. Bleach sequence conditions

\begin{tabular}{|c|c|c|c|c|}
\hline & $\mathrm{O}$ & D1 & EOP & D2 \\
\hline Temperature $\left[{ }^{\circ} \mathrm{C}\right]$ & 100 & 70 & 80 & 70 \\
\hline time [h] & 1 & 1 & 1 & 3 \\
\hline Pressure $\left[\mathrm{Kg} / \mathrm{cm}^{2}\right]$ & 4 & - & 2 & - \\
\hline Final $\mathrm{pH}$ & 11,5 & $4,0-6,0$ & 11,5 & $3,7-4,3$ \\
\hline $\mathrm{H}_{2} \mathrm{O}_{2}[\%]$ & - & 一 & 0,7 & 一 \\
\hline $\mathrm{NaOH}[\%]$ & 2,5 & 0,25 (Kraft process) & 1 & 0,1 (Kraft process) \\
\hline \multirow[t]{2}{*}{$\mathrm{ClO}_{2}[\%]$} & - & 2,59 (Kraft process) & & 0,2 (Kraft process) \\
\hline & & 1,62 (Soda process) & & 0,36 (Soda process) \\
\hline
\end{tabular}

$0,5 \%$ of $\mathrm{MgSO}_{4}$ was added during the $\mathrm{O}$ stage as carbohydrate protector; the consistency in all stages was $10 \%$

Table 2. Results of Kraft and Soda chemical pulping processes

\begin{tabular}{cccccccc}
\hline & $\begin{array}{c}\text { ACTIVE } \\
\text { ALKALI] } \\
{[\%]}\end{array}$ & $\begin{array}{c}\text { CHEMICAL } \\
\text { CONSUMPTION } \\
{[\%]}\end{array}$ & $\begin{array}{c}\text { NET } \\
\text { YIELD } \\
{[\%]}\end{array}$ & $\begin{array}{c}\text { REJECTS } \\
{[\%]}\end{array}$ & $\begin{array}{c}\text { KAPPA } \\
\text { NUMBER }\end{array}$ & $\begin{array}{c}\text { BRIGHTNESS } \\
{[\%] \text { ISO }}\end{array}$ & $\begin{array}{c}\text { VISCOSITY } \\
\text { [MPA.S] }\end{array}$ \\
\hline \multirow{2}{*}{ Kraft process } & 13 & 94,5 & 46,0 & 1,0 & 23,3 & & \\
& $13,5\left(^{*}\right)$ & 93,0 & 43,0 & 0,7 & 17,5 & 37,2 & 27,3 \\
& 14 & 90,7 & 44,1 & 0,4 & 13,0 & & \\
Soda process & 15,0 & 82,7 & 40,2 & 5,5 & 33,2 & & \\
& 15,5 & 81,8 & 42,1 & 2,0 & 25,9 & & \\
& $17,0\left(^{*}\right)$ & 74,9 & 43,6 & 0,6 & 17,7 & 41,2 & 14,2 \\
& 17,6 & 75,7 & 41,3 & 0,05 & 14,9 & & \\
\hline
\end{tabular}


Accordingly, $13,5 \%$ of AA produced a Kraft pulp with a Kappa number of 17,5 , a brightness value of $37,2 \%$ Iso, and a viscosity of $27.3 \mathrm{mPa}$.s. On the other hand, the Soda process yielded a pulp with a Kappa number of 17,7 , a brightness value of $41,2 \%$ ISO, and a viscosity of $14,2 \mathrm{mPa}$.s. The lower brightness resulting from the Kraft process must be attributed to the formation of chromophorous groups such as catechols and, to a lesser degree, hidroquinones. Moreover, the specific lignin selectivity of the reagents used in both processes is different, resulting in a higher viscosity of the Kraft pulp (Gellersted et al.,1984).

When comparing the above results with those previously obtained with eucalypt (Eucalyptus globulus, E. dunnii) kraft pulp, i.e. Kappa number of 15,3 with $15 \%$ AA (Fernández, 1988), the avocado wood proved to be easier to delignify than the eucalypts used for pulping in México.

\section{Bleaching}

\section{Exploratory bleaching $D_{1}$ stage}

Various preliminary tests were performed to establish the charge factor (CF) for chlorine dioxide $\left(\% \mathrm{ClO}_{2}=\mathrm{Kappa}\right.$ number $x \mathrm{CF}$ ) and also the soda charge as $\mathrm{pH}$ buffer during the $\mathrm{D}_{1}$ stage (Figs. 1 and 2 ) in order to obtain dependable information for optimum chemical consumption and brightness.

These tests resulted in a charge factor for the Kraft pulp of 0,24 , with a reagent load of $2,59 \% \mathrm{ClO}_{2}(17,5 \times 0,24)$, and $0,25 \%$ of alkali to be added (on OD pulp) to control the pH (Fig. 2). In comparison, the Soda pulp needed less reagent, with a charge factor of $0,18\left(1,62 \% \mathrm{ClO}_{2}\right)$, while further $\mathrm{pH}$ adjustment was not required (Fig. 1).

This different behavior between Kraft and Soda pulps can be explained by the fact that the residual lignin of the Kraft pulps is very difficult to remove during the

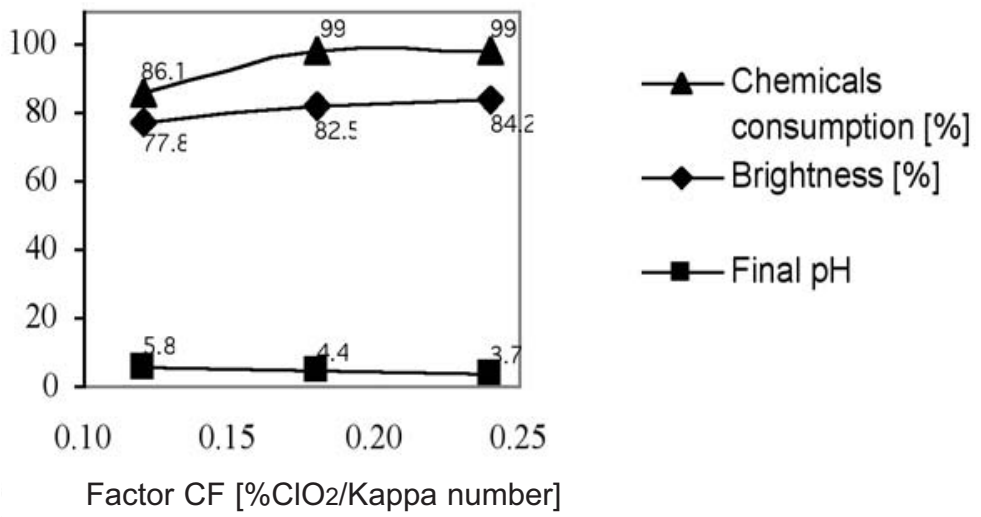

Figure 1. Effect of $\mathrm{ClO}_{2}$ charge factor (CF) on the characteristics of the Soda pulp during the exploratory bleaching stage $D_{1}$ 


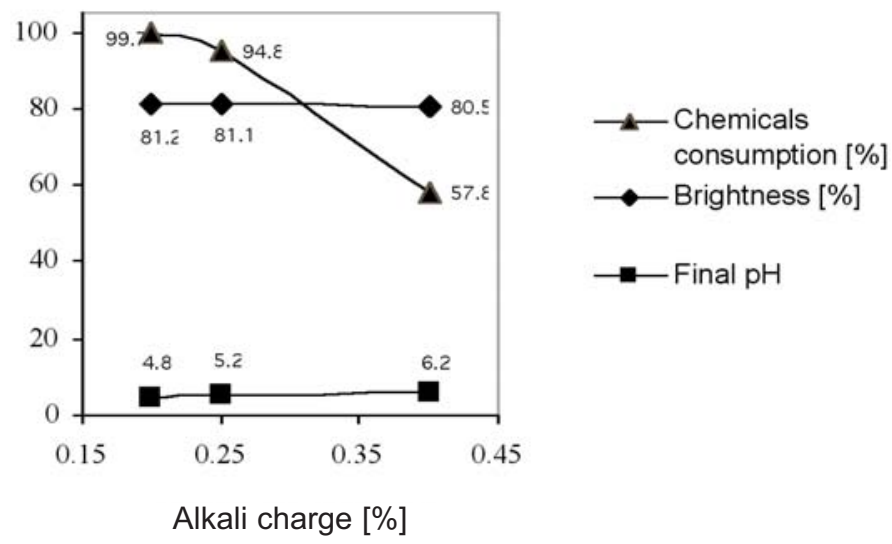

Figure 2. Effect of alkali on the Kraft pulp characteristics during the bleaching stage D1, $\mathrm{CF}=0,24$

various steps of the bleaching sequence. After $90 \%$ of the wood lignin has been eliminated when the Kappa number is around 40 , the selectivity of the kraft liquor decreases and a degradation carbohydrates is initiated (Gellerstedt et al., 1984). In addition, the presence of covalent bonds between the residual lignin and carbohydrates may also impede the removal of lignin from the pulp (Yamasaki et al., 1981).

\section{O-D1-Eop-D2 Sequence}

During the bleaching sequence the behavior of both Soda and Kraft pulps is similar (Table 3 ), except during stage $D_{1}$, which has been analyzed in the previous paragraph. The Soda pulp shows a 3\% higher initial brightness than the Kraft pulp and maintains this slightly superior level throughout the entire bleaching sequence.

On the other hand, the viscosity of the Kraft pulp decreases $7 \mathrm{mPa}$.s during the bleaching sequence, whereas that of the Soda pulp decreases by only 3 mPa.s. Nevertheless, the Soda pulp possesses a lower viscosity at the end of the bleaching process due to its lesser initial viscosity.

\section{Handsheet strength properties}

Tensile strength (Fig. 3) as well as burst (Fig. 4) and tear (Fig. 5) indexes of Soda and Kraft pulps were determined. For comparison, the respective data for bleached eucalypt pulp hand sheets (Fernández, 1998) are included with the three figures. The bleaching process did not significantly reduce any of the strength properties assessed. Moreover, the avocado Kraft pulp showed a rather high tensile strength compared to all other pulps. Equally, the Kraft and Soda pulps tear index (Fig. 4) remain largely unaffected by the bleaching process excepting the lower range of the refining degree. The burst index (Fig. 5) increases with the bleaching for the Kraft pulp, whereas the Soda pulp does not present changes induced by bleaching. On average, the strength properties of Kraft pulps were higher than those of the Soda pulps. 
Table 3. Results of bleaching sequence of avocado wood Kraft and Soda pulps

\begin{tabular}{|c|c|c|c|c|}
\hline \multirow[t]{2}{*}{ PARAMETER } & \multicolumn{3}{|c|}{ KRAFT PULP } & \multirow[b]{2}{*}{ D2 } \\
\hline & $\mathrm{O}$ & D1 & EOP & \\
\hline Kappa number & 10,8 & 2,3 & 0,6 & - \\
\hline Yield [\%] & 97,4 & 95,4 & 96,6 & 96,7 \\
\hline Chemical consumption [\%] & 82,9 & 86,6 & $\begin{array}{r}97,6(p) \\
100(s)\end{array}$ & 66,1 \\
\hline Brightness [\%] & 53,6 & 80,2 & 86,5 & 88,9 \\
\hline Viscosity [mPa.s] & 24,6 & 20,4 & 16,9 & 17,1 \\
\hline \multirow[t]{2}{*}{ Final $\mathrm{pH}$} & 11,8 & 3,2 & 9,6 & 6,3 \\
\hline & \multicolumn{3}{|c|}{ SODA PULP } & \\
\hline Kappa number & 10,1 & 2,9 & 2,0 & - \\
\hline Yield [\%] & 96,9 & 97,8 & 99,3 & 99,8 \\
\hline Chemical consumption [\%] & 100 & 96,5 & $\begin{array}{l}93,8(p) \\
95,8(s)\end{array}$ & 79,6 \\
\hline Brightness [\%] & 55,2 & 81,9 & 88,5 & 91,7 \\
\hline Viscosity [mPa.s] & 13,8 & 11,9 & 11,0 & 11,0 \\
\hline Final pH & 10 & 3,7 & 10 & 4,1 \\
\hline
\end{tabular}

$(p)$ = peroxide; $(s)=$ soda

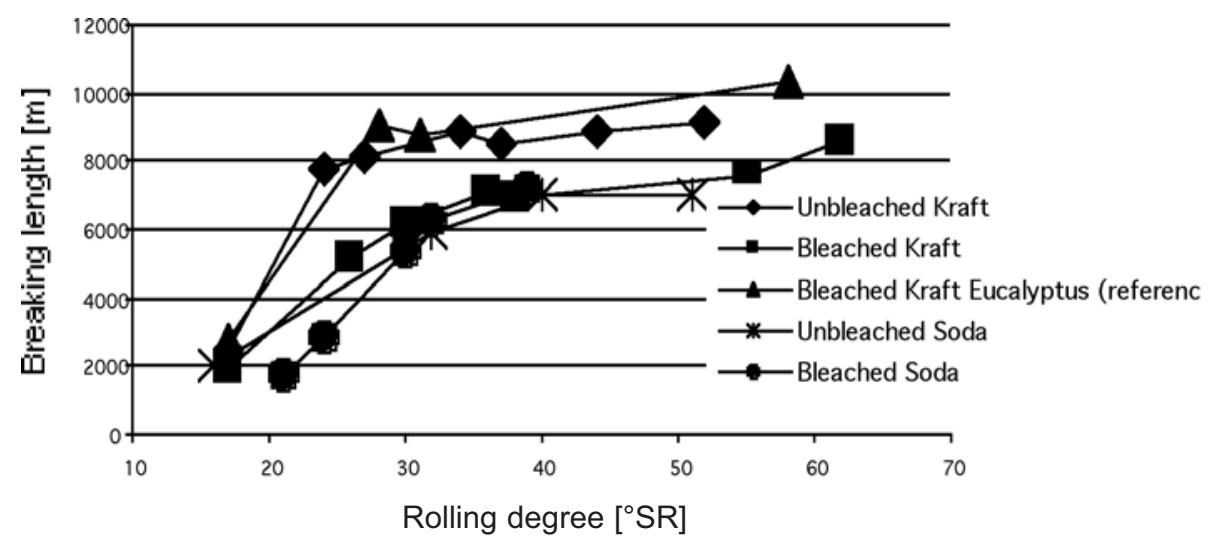

Figure 3. Breaking length of Kraft and Soda unbleached and bleached pulps as a function of the refining degree 


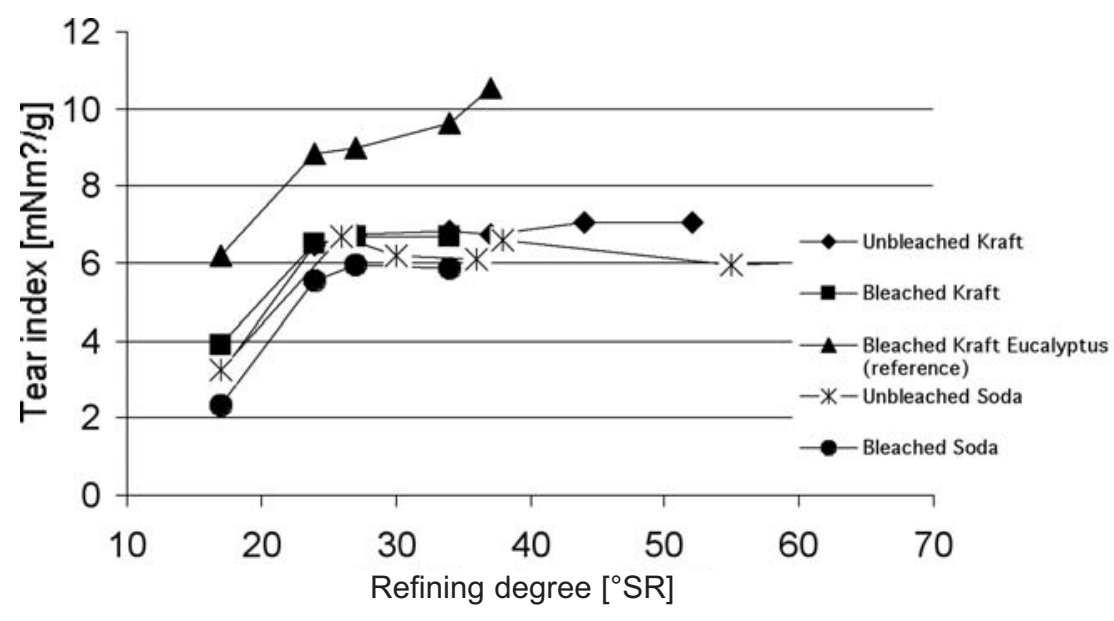

Figure 4. Tear index of Kraft and Soda unbleached and bleached pulps as a function of the refining degree

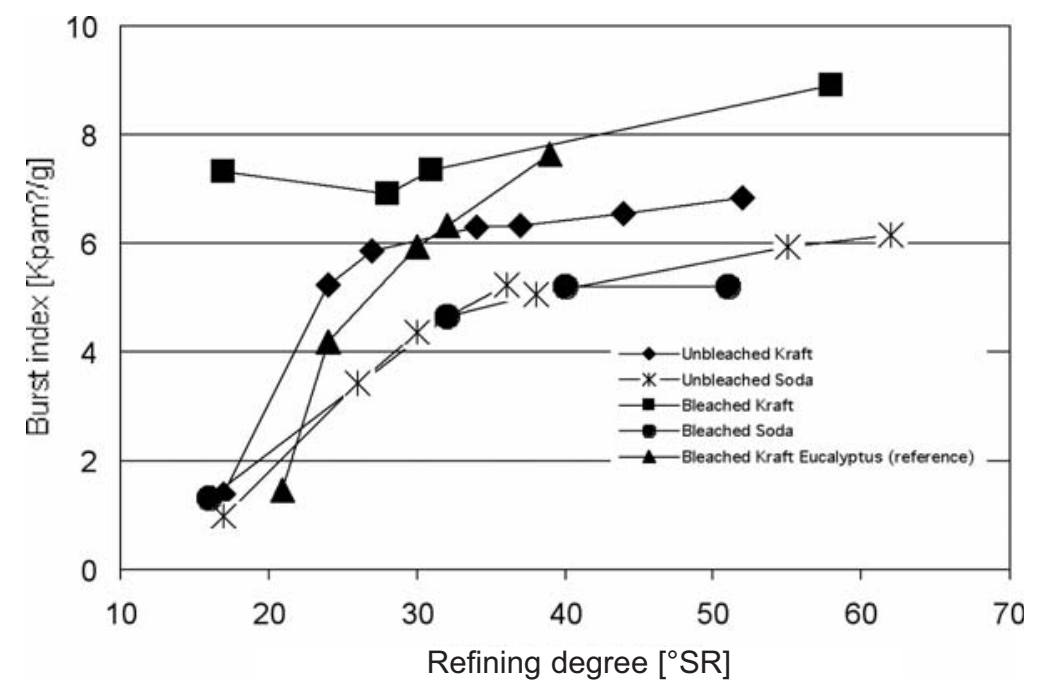

Figure 5. Burst index of Kraft and Soda unbleached and bleached pulps as a function of the refining degree 
The comparison of the avocado pulps with the eucaypt pulp reveals similar values of the burst index, higher breaking length, and lower values of the index except for Avocado bleached soda pulp which has tear index similar to that of eucalypt pulp.

\section{CONCLUSIONS}

Kraft and Soda pulps of avocado wood subjected to a bleaching sequence $\mathrm{O}-\mathrm{D}_{1}-\mathrm{E}_{\mathrm{op}}-\mathrm{D}_{2}$ could attain competitive commercial brightness levels (88-92\% ISO) with low chloride dioxide concentration. This is more evident in Soda pulps and this pulp is also easier to bleach than the Kraft pulp.The viscosity of Soda pulps is lower than that of Kraft pulps; therefore strength properties of bleached and unbleached Kraft pulps are higher than the equivalent Soda pulps.

Avocado wood pulps compare favorably with commercial eucalypt pulps (Eucalyptus spp.) and thus constitute a viable alternative as cellulose fiber supply.

\section{REFERENCES}

FAOSTAT 2004: Database at http://faostat. fao.org/

Fernández, L.E. 1998. Investigaciones en pulpa Kraft de Eucalyptus globulus Labill., ssp globulus y Eucalyptus dunni Maiden de bosques técnicos tendientes a mejorar sus propiedades ópticas y mecánicas. MC tesis; Departamento de Madera, Celulosa y Papel, Universidad de Guadalajara, México.
Hatton, J.V. 1979. Chip quality. Monograph No. 5. Pulp and Paper Technology Series. Joint textbook committee of the paper industry, TAPPI Press.

Gellerstedt, G. and E.V. Lindfors. 1984. Structural changes in lignin during Kraft pulping. Holzforschung 38: 151-158.

Kopp, L.E. 1966. A taxonomic revision of the genus Persea (Lauraceae) in the western hemisphere. Memories of the New York Botanical Garden 14:1-120.

López, J. 1999. Personal communication. Presidente de la Asociación Agrícola de Productores de Aguacate de Uruapan, Michoacán. Independencia No 11. Uruapan, Michoacán.Record, S.J.\& R. Hess 1944. Timber of the New World. Yale University Press, New York, 640 pp.

Senior, D.J., J. Hamilton, A.J. Ragauskas, J. Sealey and P. Froass 1998. Interaction of hydrogen peroxide and chlorine dioxide stages in ECF bleaching. Tappi Journal 8 (6): pp 170-178.

Silva G.,J.A., F.J. Fuentes T., H.G. Richter, G. Álvarez A. and R. Sanjuán D. 1999. Estructura de la madera de Persea americana Mill. var. guatemalensis (Hass). Madera y Bosques 5(1): 53-59.

Yamasaki, T., S. Hosoya, L. Chen, H. Gratz and M. Chang 1981. Proceedings Characterization of residual lignin in Kraft pulp. International Symposium on Wood and Pulping Chemistry, Stockholm, vol. 2, pp. 34-42.

Manuscrito recibido el 17 de mayo de 2005.

Aceptado el 12 de diciembre de 2005.

Este documento se debe citar como:

Vargas, R., J.R. Sanjuán D., J.A. Silva G., J. Rivera P., F.J. Fuentes T. y H.G. Richter. 2006. Properties of bleached pulp sheets of avocado wood (Persea americana Mill.) pulped by Kraft and soda processes. Madera y Bosques 12(1):29-36. 